\title{
Fair Trade, Formal Equality, and Preferential Treatment
}

\author{
James Christensen \\ Final version available here: \\ http://www.jstor.org/stable/24575742?seq=1\#page scan tab contents
}

\begin{abstract}
This paper criticizes the claim that fair trade entails a commitment to an ideal of formal equality according to which all members of the trade regime are to receive and offer equal, or uniform, treatment. The first section elaborates upon the idea of formal equality and its rationales, identifies several positive arguments for departing from formal equality, and responds to a number of objections to "special and differential treatment" for poor countries. Next, in section II, the paper considers in more detail one specific element of formal equality in the trade regime, namely, the principle of reciprocity. Three distinct reciprocity principles are identified, none of which, it is argued, should be regarded as a requirement of fairness. Section III considers a more recent interpretation of formal equality which requires trading countries to "harmonize" domestic laws and policies. It is argued that harmonization is not required by fairness.
\end{abstract}

Keywords: Fair Trade; Global Justice; World Trade Organization; Formal Equality; Special and Differential Treatment; Reciprocity; Harmonization

It is sometimes said that the World Trade Organization (WTO) is, in one respect, fundamentally egalitarian. It is fundamentally egalitarian in the sense that it is committed to an ideal of formal equality according to which all member states are to receive and offer equal, or uniform, treatment. This commitment to formal equality is expressed in various ways. It is expressed, for example, in the principle of non-discrimination (embodied in the Most Favoured Nation and National Treatment rules) and the principle of reciprocity. The Most Favoured Nation rule (MFN) requires WTO member states to refrain from treating any members less favourably than they treat others. If a state offers a privilege (e.g. a tariff concession) to another state, it must extend that privilege to all WTO members. The National Treatment rule (NT) requires states to refrain from treating imports less favourably than they treat domestically produced goods; once foreign goods have passed customs and entered the domestic market, the taxes and regulations which apply to them must not differ from those applied to domestically produced goods. And the principle of reciprocity requires states to match the liberalization efforts of others; if, during a 
round of negotiations, one state promises to cut tariffs by $\mathrm{x}$ per cent, other states are also expected to cut tariffs by x per cent. The commitment to formal equality is also expressed in the WTO's egalitarian and majoritarian voting system.

Formal equality has been championed by developed countries, but it has been challenged by poorer members of the trade regime. Throughout the trade regime's history, developing countries have demanded various forms of preferential treatment - often referred to as "special and differential treatment" $\left(\right.$ SDT) ${ }^{1}$ - and their demands have sometimes been acceded to. ${ }^{2}$ For example, Part IV of the General Agreement on Tariffs and Trade (GATT), which was added in 1965, restricts the application of the reciprocity principle to developed countries, and the Generalized System of Preferences (GSP), initiated in 1968, permits developed countries to deviate from MFN by imposing lower tariffs on imports from developing countries. Also, developing countries have sometimes enjoyed the freedom to refrain from signing agreements which they felt were not in their interest. During the Tokyo Round of negotiations, for example, many developing countries were able to refrain from signing a number of agreements on reducing the incidence of non-tariff barriers. In recent years, new forms of SDT have been mooted - including technology transfers from developed to developing countries, and payments to help the latter implement obligations and to build their negotiating capacity - but opponents of SDT have not gone away.

This paper considers whether we have moral reasons to endorse formal equality within the trade regime, and pays particular attention to the relationship between formal equality, on the one hand, and fairness or justice, on the other. The thrust of my argument is that formal equality,

\footnotetext{
1 On SDT see, for example, Christopher Stevens, "Special and Differential Treatment", in Ivan Mbirimi, Bridget Chilala, and Roman Grynberg (eds.) From Doha to Cancun: Delivering a Development Round (London: Commonwealth Secretariat, 2003); Alexander Keck and Patrick Low, "Special and Differential Treatment in the WTO: Why, When, and How?", in Simon Evenett and Bernard M. Hoekman (eds.) Economic Development and Multilateral Trade Cooperation (New York: Palgrave Macmillan, 2006); Michael J. Trebilcock and Robert Howse, The Regulation of International Trade $3^{\text {rd }}$ Edition, (New York: Routledge, 2005) Ch. 15.

2 See Chin Leng Lim, "The Conventional Morality of Trade", in Chios Carmody et al. (eds.), Global Justice and International Economic Law: Opportunities and Prospects (New York: Cambridge University Press, 2012).
} 
as that idea has been interpreted and applied in the context of trade, is not an ideal to which we should aspire. But, as will become clear, the issue cannot be fully resolved through philosophical analysis alone. The paper is structured as follows. The first section elaborates upon the idea of formal equality and its rationales, identifies several positive arguments for departing from formal equality, and responds to a number of objections to SDT. Next, in section II, I consider in more detail one specific element of formal equality in the trade regime, namely, the principle of reciprocity. Three distinct reciprocity principles are identified, none of which, it is argued, should be regarded as a requirement of fairness. Section III considers a more recent interpretation of formal equality which requires trading countries to "harmonize" domestic laws and policies. I argue that harmonization is not required by fairness.

In recent decades, notions of fair and just trade have become increasingly widespread. Trade representatives, worker's organizations, corporations, and various NGOs have advanced a variety of ideas about what fairness in trade requires. Slowly but surely, philosophers have begun to participate in this debate. They have addressed questions such as: (i) what can be traded, and with whom? $?^{3}$; (ii) should trade be restricted in order to, say, protect jobs or preserve cultural distinctiveness? ${ }^{4}$; and (iii) should the national income gains created by trade be distributed according to a certain (e.g. egalitarian) pattern ${ }^{5}$ This paper addresses important aspects of the fair trade debate which have not yet received adequate philosophical scrutiny.

\section{Formal Equality and Preferential Treatment}

\footnotetext{
${ }^{3}$ For one aspect of this debate see James Christensen, "Weapons, Security, and Oppression: A Normative Study of International Arms Transfers", The Journal of Political Philosophy, Vol. 23, No. 1, 2015.

${ }^{4}$ Mathias Risse, "Fairness in trade I: obligations from trading and the pauper-labor argument", Politics, Philosophy \& Economics, Vol. 6, No. 3, 2007; Malgorzata Kurjanska and Matthias Risse, "Fairness in Trade II: Export Subsidies and the Fair Trade Movement", Politics, Philosophy \& Economics, Vol. 7, No. 1, 2008; Fernando R. Teson, "Why Free Trade is Required by Justice", Social Philosophy and Policy, Vol. 29, No. 1, 2012.

5 Aaron James, Fairness in Practice: A Social Contract for a Global Economy (Oxford: Oxford University Press, 2012).
} 
Is formal equality within the trade regime desirable? Should we heed calls to abolish SDT, or seek to maintain and extend it? We can start to answer these questions by examining in more detail the idea of formal equality and the considerations which support it. Note that formal equality is an ambiguous concept. It is used to refer both to the claim that (i) all individuals (or all members of a particular practice) must receive equal (uniform, identical) treatment ${ }^{6}$, and to the claim that (ii) all individuals (or all members a particular practice) who are comparable in relevant respects must receive equal (uniform, identical) treatment - that is, to the principle that like cases should be treated alike. ${ }^{7}$ Given that any statement of (ii) presupposes an account of which respects are relevant, (ii) can easily collapse into (i). Suppose a university claims to adhere to the principle that like cases should be treated alike. And suppose that individuals are deemed to be alike provided that they are a member of the university. It follows that the university's policy of treating like cases alike is indistinguishable from a policy of treating all members identically.

One might say that when developed members of the trade regime champion the idea of formal equality, they are championing the idea that like cases should be treated alike. But, to the degree that this is true, the developed country advocates of formal equality have worked with an implicit account of relevant respects according to which member states and their citizens are not deemed to be unalike by virtue of differential levels of economic development. The developing countries and their citizens may be poorer than the developed countries and developed-country citizens, but both sets of countries, and both sets of citizens, are deemed to be alike in all respects that are relevant, and it is said that they should therefore receive, and be expected to offer, uniform treatment.

Formal equality within the trade regime might be endorsed for a variety of pragmatic reasons: when expectations are uniform it may be easier for states to identify what is required of

\footnotetext{
${ }^{6}$ See, for example, Patricia Hughes "Recognizing Substantive Equality as a Foundational Constitutional Principle", Dalhousie Law Journal, Vol. 22, No. 5, 1999, p. 27; Lim, op.cit.

7 See, for example, Charles Frankel, "Equality of Opportunity", Ethics, Vol. 81, No. 3, 1971, pp. 193-194; Catherine Barnard and Bob Hepple, "Substantive Equality", Cambridge Law Journal, Vol. 59, No. 3, 2000, pp. 562-564.
} 
them; uniform rules are easier to administer and enforce; and uniform rules might facilitate the process of trade liberalization. Formal equality might also be defended for reasons of equity. Departures from formal equality often confer advantages upon one set of individuals, and if all individuals are deemed to be alike in relevant respects the conferral of such advantages can be seen as unfair. If there are no relevant differences among individuals, there can be no grounds for treating one set differently and more favourably than others. The problem with this argument when applied in the context of trade is that it is very difficult to defend the claim that all members of the trade regime are alike in relevant respects. More specifically, the claim that differential levels of economic development do not constitute a relevant difference is highly suspect. Indeed, the fact that some members of the trade regime are very poor might be thought to give us a strong prima facie reason to depart from formal equality, and to advocate preferential treatment for poorer states.

The case for departing from formal equality and offering special and differential treatment to poor countries can be given several more specific rationales. First, one might advocate SDT on the grounds that it enables wealthy states to discharge positive duties of assistance to the global poor. Many philosophers have defended the claim that citizens of affluent countries have positive duties to contribute to the alleviation of global poverty, at least when they can do so at little cost to themselves, and one might argue that SDT provides an opportunity to discharge such duties. ${ }^{8}$ Alternatively, one might advocate SDT on the grounds that it enables wealthy states to discharge rectificatory duties; that is, duties to compensate for the infliction of harm. According to some critics, rich countries are guilty not (or not merely) of failing to discharge positive duties to help the poor, but of violating negative duties to refrain from harming them. Scholars and activists who take this view hold that rich countries are implicated in the poor's plight. Colonial practices have inflicted long-lasting damage on poor

\footnotetext{
8 The classic defence of positive duties to alleviate poverty is Peter Singer, "Famine, Affluence, and Morality", Philosophy \& Public Affairs, Vol. 1, No. 3, 1972.
} 
countries, and the contemporary global order is structured in a way that continues to undermine their development prospects. ${ }^{9}$ If rich countries are guilty as charged, their primary duty must be to stop inflicting harm. But they will also have duties to compensate for harms they have already caused. SDT might, then, be justified as a way of discharging those rectificatory duties: giving poor countries extra now might be seen as a way of making up for what the rich have taken in the past. In order for these two arguments to go through, one would have to show not only that SDT is, in fact, an effective tool for discharging positive and rectificatory duties, but also that there are not acceptable alternatives which do not involve deviations from formal equality.

SDT might also be defended on the grounds that it is necessary to ensure an equitable distribution of the benefits and burdens associated with participation in the trade regime. Egalitarian theory has long recognized that, because people differ in important respects, equal (or uniform) rights may be insufficient to secure genuine equality. This line of reasoning can be used to support SDT. Given the huge differences between the abilities and needs of developed and developing countries, a set of rules with which the former can easily comply might be excessively demanding for the latter. Complying with WTO rules is often more demanding for poor countries. This is for a variety of reasons: poor countries have weaker safety nets, and are thus less able to protect workers displaced by trade liberalization; their administrative systems typically require greater reform; and implementing trade agreements requires expenditure of resources which could otherwise be spent on development programmes. ${ }^{10}$ It can therefore be argued that differential treatment is appropriate as it can ensure a more equal and equitable distribution of benefits and burdens.

\footnotetext{
9 Thomas Pogge's oeuvre offers the most sophisticated statement of this view. See, for example, Thomas Pogge World Poverty and Human Rights: Second Edition (Cambridge: Polity Press, 2008). For a helpful overview of the literature on the effects of colonial practices on economic development, see Nathan Nunn, "The Importance of History for Economic Development", Annual Review of Economics, Vol. 1, 2009.

${ }^{10}$ Joseph E. Stiglitz and Andrew Charlton, Fair Trade for All: How Trade can Promote Development (Oxford: Oxford University Press, 2005), Chapter 13.
} 
Each of the arguments briefly sketched above provides resources with which to justify departures from formal equality, and vindicate preferential treatment for poor countries. But they might be countered with a variety of objections, to which we should now turn.

\section{Objections}

It might be argued that SDT (i) undermines the bargaining power of poor countries; (ii) is unfair; or (iii) directly harms the economies of poor countries. Let us consider these three objections in turn.

\section{Diminished Bargaining Power}

It is sometimes argued that SDT is counter-productive because it undermines the bargaining power of the poor. According to this argument, poor countries will only be granted access to important markets in the developed world if they offer rich countries something in return. But SDT permits and encourages poor countries to offer few concessions, and, consequently, they receive little from the rich. The objection is well articulated by Peter Lichtenbaum, who writes:

Developing countries have been unable to obtain significant concessions on products of interest to them from developed economies by failing to participate in the exchange of reciprocal reductions in trade barriers. For example, industrialized countries singled out textiles and agriculture, which are important products for developing countries, and subjected these industries to extremely high import restrictions... [T] he long-term interests of developing countries may be better served if they were able to improve their negotiating position by offering to liberalize their economies and open their markets to import competition. In this way, developing countries could bargain more effectively to obtain market access on products of interest to their economies. ${ }^{11}$

11 Peter Lichtenbaum, ““Special Treatment” vs. "Equal Participation:” Striking A Balance In The Doha Negotiations", The American University International Law Review, Vol. 17, No. 5, 2002, pp. 1017-1018, footnote omitted. Cf. Constantine Michalopoulos, "Developing Country Strategies for the Millennium Round", Journal of World Trade, 
It is important to be clear about what it being said here. The claim is not that SDT directly or necessarily hurts the interests of poor countries. Rather, the claim is that when poor countries avail themselves of the opportunities made available by SDT, rich countries react in a particular way - namely, they single out products of special importance to poor countries and impose upon those products inordinately high tariffs. Rich countries give with one hand - by acceding to demands for SDT - but take away with the other. Now, it should be obvious that the argument currently under scrutiny - SDT should be abandoned because it hurts the interests of the poor cannot be made in good faith by rich members of the WTO. The rich cannot object to SDT on the grounds that it is bad for the poor if it is their own voluntary actions which make it bad for the poor. As G. A. Cohen famously pointed out,

an argument changes its aspect when its presenter is the person, or one of the people, whose choice, or choices, make one or more of the argument's premises true. By contrast with other presenters of the same argument, a person who makes, or helps to make, one of its premises true can be asked to justify the fact that it is true..$^{12}$

Poor countries might decide that, given how the rich have acted in the past and can be expected to act in the future, they have prudential reasons for eschewing SDT. But things are very different for rich countries. We can ask rich countries to justify their decision to act in the way they do when poor countries make use of the options given to them by SDT, and an acceptable justification is unlikely to be forthcoming.

\section{Unfairness}

Special and differential treatment is sometimes compared to domestic affirmative action policies which require firms and universities to give preferential treatment to applicants from

Vol. 33, 1999, No. 5, p. 25; and Ethan Kapstein, Economic Justice in an Unfair World: Toward a Level Playing Field (Princeton, NJ: Princeton University Press, 2006), pp. 70-71.

${ }^{12}$ G. A. Cohen, Rescuing Justice \& Equality (Cambridge, Mass: Harvard University Press, 2008), pp. 38-39, footnote omitted. 
disadvantaged groups. ${ }^{13}$ If affirmative action and SDT are comparable, the latter may be vulnerable to some of the objections commonly levelled at the former. Let us consider this possibility. Perhaps the strongest objection to affirmative action is that it unfairly deprives talented individuals of jobs and university places which they would have secured in the absence of affirmative action. Those who make this objection sometimes acknowledge that we are not dealing with like cases, but maintain that differential treatment is nevertheless unfair.

The most obvious analogue to this objection focuses on the effects of SDT on rich world firms. These firms will be denied access to certain markets, their developing-world competitors will be strengthened, and their economic vitality may well be undermined. We can begin to formulate a response to this objection by considering how one should reply to the complaint that affirmative action denies talented individuals access to positions which would otherwise have been available to them. Notice that this complaint invokes an inappropriate counterfactual. The relevant counterfactual consideration is not who would have secured which position in a scenario identical to the status quo except for the absence of affirmative action policies, but rather who would have secured which position in a scenario in which (i) affirmative action policies were never introduced and (ii) where the injustices which motivated those policies never occurred. While it is surely true that in a society disfigured by racial injustice certain white applicants would be offered jobs and university places which they would not have been offered had affirmative action programmes been in operation, it is much less likely that those same applicants would have been offered those positions had segregation and other forms of racial injustice not incapacitated potential black competitors.

Similarly, one might argue that rich-world firms are invoking an inappropriate counterfactual when they complain that they are denied opportunities which they would have enjoyed if SDT had never been introduced and all other variables had remained the same. The

13 Gillian Moon, "Trade and Equality: A Relationship to Discover", Journal of International Economic Law, Vol. 12, No. 3, 2009, pp. 622-23; Kapstein, op. cit., p. 70. 
relevant counterfactual, it can be argued, is how those firms would have fared if (i) SDT had never been introduced and (ii) many of their foreign rivals were not operating in countries crippled by colonial plunder and the extant machinery of global injustice. If we endorse the second of the three positive arguments for SDT adumbrated in the previous subsection according to which rich countries are complicit in the creation and maintenance of world poverty - this response is readily available to us.

Equally pertinent is the fact that even in a free global market without SDT rich world firms would not prosper simply by virtue of being more efficient than their foreign rivals. To the degree that rich world firms object to SDT on the grounds that it enables less efficient companies based in developing countries to outcompete them in the global market, they are betraying their economic ignorance; they may be outdone by their less efficient foreign rivals even in the absence of SDT. A firm operating in Country A and Industry P may be more efficient than its counterparts in Country B, but the theory of comparative advantage tells us that if Country A firms operating in Industry Q are even more efficient vis-à-vis their counterparts in Country B, Country A firms in Industry P may well lose out from free trade. ${ }^{14}$

In the US, practices such as affirmative action which sanction granting preferential treatment to certain groups of citizens are sometimes accused of violating the Fourteenth Amendment of the Constitution which guarantees "equal protection of the laws". SDT practices which grant preferential treatment to certain countries, and deviate from MFN, NT, and the reciprocity principle, may be conceived of as analogous transgressions. It is thus instructive to consider how the US courts have responded to these accusations. ${ }^{15}$

\footnotetext{
${ }_{14}$ On this point see Douglas A. Irwin, Free Trade Under Fire: Third Edition (Princeton, NJ: Princeton University Press, 2009), pp. 33-34.

15 The following paragraph draws on Ronald Dworkin, Sovereign Virtue: The Theory and Practice of Equality, (Cambridge, Mass: Harvard University Press, 2000) pp. 412-413.
} 
In order to assess claims that a piece of legislation violates the equal protection clause of the Constitution, the American courts follow a two stage procedure. The goal of the first stage is to establish whether the law in question seriously disadvantages what the Supreme Court has referred to as a "suspect class", namely, a group "saddled with such disabilities, or subject to such a history of purposeful unequal treatment, or relegated to such a position of political powerlessness as to command extraordinary protection from the majoritarian political process." ${ }^{\prime 16}$ If the law seriously disadvantages a suspect class then the purpose of the second stage is to subject the law to "strict scrutiny". If, on the other hand, those disadvantaged by the law do not belong to a suspect class, the law is subjected to "relaxed scrutiny". A law subject to strict scrutiny will be regarded as unconstitutional unless the disadvantage it generates can be shown to be necessary for the protection of a "compelling" governmental interest. By contrast, a law subject to relaxed scrutiny will be regarded as constitutional unless it can be shown to serve no purpose whatsoever.

Suppose we were to assess SDT using a similar procedure. It seems that SDT should only be subject to relaxed scrutiny, for the rich world firms it disadvantages clearly do not belong to a suspect class. Thus, SDT would be vindicated provided that it could be shown to serve a worthwhile end. The positive arguments sketched in the previous subsection each identify worthwhile ends - fulfilment of positive duties; fulfilment of rectificatory duties; and equitable distribution of benefits and burdens. Consequently, provided one can demonstrate that SDT is an effective means of achieving those ends, SDT would be justified. ${ }^{17}$

\section{Economic Harm}

\footnotetext{
${ }^{16}$ Justice Powell, quoted in ibid., p. 412.

${ }^{17}$ When developing countries use SDT measures to restrict imports from countries at a comparable or lower level of development such measures assume a more worrying character. Perhaps such uses should be proscribed. On this point see Peter Kleen and Sheila Page, "Special and Differential Treatment of Developing Countries in the World Trade Organization”, Global Development Studies, No. 2, 2005, p. 50.
} 
As we saw above, it is sometimes claimed that SDT is counter-productive because it diminishes the bargaining power of the poor countries it is supposed to help. But SDT is commonly criticized on the grounds that it harms the economies of poor countries in a more direct fashion. Many economists and policy makers believe that free trade promotes growth and development, and they criticize SDT because it permits poor countries to employ protectionist measures which undermine their development prospects. ${ }^{18}$ The relationship between free trade, growth, and development is a matter best left to economists, but that does not mean that there is nothing to be said here. Rather, we should emphasize that SDT comes in many different varieties. While it might be true that free trade promotes development, and that protectionist policies inhibit it, it does not follow from such facts that all conceivable forms of SDT will be economically harmful, for not all forms of SDT permit developed countries to employ protectionist measures. Monetary payments or technology transfers, for example, do not permit or encourage protectionism. Indeed, it is important to distinguish between the abstract idea or concept of granting special treatment to poor countries, and specific conceptions of that idea which describe the form which special treatment should take. While particular conceptions of special treatment (e.g. those which permit the use of protectionist measures) might be economically harmful, the claim that the concept of special treatment must inevitably be expressed in policies which will hurt the interests of developing countries is implausible.

This concludes the first section. We have explicated the idea of formal equality, identified several arguments for departing from formal equality, and seen how departures in the form of

\footnotetext{
18 Trade can promote growth through a variety of channels. For example, trade exposes domestic firms to foreign competition which gives them a strong incentive to become more efficient: if they do not, they may not survive. Trade can also encourage growth by facilitating the transfer of technology and knowledge. Firms in one country are made aware of novel production processes and business methods used by firms in other countries, and are thus able to become more efficient. And, to take one final example, by expanding the size of the market, trade enables firms to take advantage of economies of scale. Some economists think that poor countries would benefit considerably from opening their markets, but others disagree. The most well-known, and robust, argument in favour of closure is the "infant-industry argument". Famously defended by John Stuart Mill, this argument maintains that countries can benefit from employing protectionist measures in order to nurture new firms which are not ready to compete in the global market. Helpful, non-technical, statements of the case for free trade are presented in Stiglitz and Charlton, op. cit., Ch. 2, and Irwin, op. cit., Ch. 2. For discussion of the infant industry argument, see Douglas A. Irwin, Against the Tide: An Intellectual History of Free Trade (Princeton, NJ: Princeton University Press, 1996), Ch. 8.
} 
SDT can be defended against a number of objections. I do not claim to have offered a full vindication of SDT, but rather to have performed some of the philosophical groundwork that is necessary for the achievement of such a vindication. As we have seen, whether any particular conception of SDT can be fully vindicated depends upon the resolution of important economic questions regarding the efficacy of that conception.

\section{II}

\section{The Principle of Reciprocity}

The analysis in the previous section did not differentiate between the various expressions of formal equality found in the WTO (non-discrimination, reciprocity, etc.) In this section I focus on one particular expression of formal equality, namely, the principle of reciprocity. Whereas section I defended departures from formal equality by appealing to the needs of developing countries, this section reveals that some fairness-based demands for formal equality run into trouble even if we bracket those needs. I do, however, appeal to the needs of developing countries in order to defeat what I call the "special interest" conception of reciprocity.

Reciprocity means different things in different contexts and disciplines. In the study of world politics, reciprocity is a characteristic of interstate relations which is said to obtain when all parties make roughly equivalent contributions to a shared endeavour. A state behaves reciprocally when it acts in a way which is conducive to the achievement of reciprocity, i.e. by aiming to match the efforts of others. ${ }^{19}$ It is this notion of reciprocity which I will be referring to throughout this section. This notion of reciprocity is usually conceived of as a strategy for

\footnotetext{
${ }^{19}$ The idea of reciprocity as understood by scholars of International Relations is actually more complex than this. In addition to equivalent contributions it also requires that states make their behaviour conditional upon the behaviour of others. Moreover, reciprocity is not only a characteristic of cooperative endeavours; a state acts reciprocally when, for example, it fires a nuclear weapon at a state which has just fired a nuclear weapon at it. However, the definition given in the text is adequate for present purposes. See Robert Keohane, "Reciprocity in International Relations", in his International Institutions and State Power: Essays in International Relations Theory, (Boulder, CO: Westview Press, 1989).
} 
achieving cooperation in an anarchic world order. But it is also sometimes said to be a requirement of fairness.

In the context of international trade, reciprocity is often regarded as a crucial value. As Andrew Brown and Robert Stern point out, in "bilateral trade negotiations, negotiators have often directly compared, product by product, the size of the tariff cuts and the volume of trade in order to assure themselves of equivalence." 20 This insistence on what has been called specific reciprocity has been replaced in recent decades by diffuse reciprocity. ${ }^{21}$ Brown and Stern observe that

in recent negotiations among developed countries, a rough sense of equivalence could be perceived to have guided them even if there was no close accounting of the gains in market access. In each of the major areas of negotiation, the mutual concessions among these countries were roughly comparable..$^{22}$

It is sometimes said that, in the absence of rough equivalence of concessions, unfairness obtains. Indeed, a number of US firms have insisted that fair trade requires nothing less than strict equivalence, or specific reciprocity. ${ }^{23}$ But such claims are insensitive to a highly relevant consideration, namely, how liberal each country was at the start of negotiations. If Country A enters a round of negotiations with, say, very few tariff barriers, while Country B enters the round with very many tariff barriers, it hardly makes sense to say that the outcome of the negotiations is unfair simply by virtue of the fact that Country A agreed to fewer tariff reductions than Country B.

If $\mathrm{A}$ has a lower level of tariffs because it has made more reductions than $\mathrm{B}$ in the past, $\mathrm{A}$ can rightly insist that those reductions be taken into consideration when measuring each

\footnotetext{
20 Andrew G. Brown and Robert M. Stern, "Concepts of Fairness in the Global Trading System”, Pacific Economic Review, Vol. 12, No. 3, p. 300

${ }^{21}$ These terms were coined in Keohane, op. cit., p. 134. Specific reciprocity "refer[s] to situations in which specified partners exchange items of equivalent value in a strictly delimited sequence..." Diffuse reciprocity, by contrast, refers to situations in which "the definition of equivalence is less precise..."

22 Brown and Stern, op. cit., p. 300, emphasis added.

${ }^{23}$ Kenneth W. Abbott, "Defensive Unfairness: The Normative Structure of Section 301", in Bhagwati and Hudec (eds.), Fair Trade and Harmonization: Volume 2 - Legal Analysis, (Cambridge, Mass: MIT Press, 1996) pp. 425-28
} 
country's relative contribution and determining how many reductions each country should make in the future. Alternatively, if A has always maintained fewer tariff barriers than B, it can point out that, all along, it has offered $\mathrm{B}$ greater access to its market. Either way, expecting A to commit to the same number of future reductions as $\mathrm{B}$ is to demand more of $\mathrm{A}$ than of $\mathrm{B}$. $\mathrm{B}$ might point out that by reducing tariffs by x percent it will incur a certain level of costs, and that unfairness obtains unless A commits to reductions which entail costs of a comparable level. But A can maintain that it has borne such costs in the past. Moreover, given that B's market is currently more protected than A's, B has more to gain from liberalization - more precisely, B has more to gain from beginning the liberalization process than A does from further liberalization and the costs B incurs can therefore be offset to a greater degree.

These points have not been lost on many US firms who have been quick to advance an alternative conception of reciprocity according to which what matters is not the level of concessions made during any given round of negotiations, but rather the relative openness of countries' markets. Proponents of this conception of reciprocity, which has been called the equal access conception ${ }^{24}$, allege that trade is fair when markets in all countries are equally accessible. The equal access conception of reciprocity comes in two varieties: national equal access reciprocity and sectoral equal access reciprocity. ${ }^{25}$ According to the former, there must be equal access at the national level; the incidence of tariffs and other protectionist measures in one country must be no higher than the incidence of protectionist measures in other countries. On this view, the distribution of protectionist measures is unimportant. Country A may protect its agricultural industry to a greater extent that Country B, but, if Country B protects its textile industry to a greater extent than Country A, the demands of equal access reciprocity may nevertheless be satisfied. According to sectoral equal access reciprocity, by contrast, the distribution of market access must be the same in all countries. If Country B has few agricultural

\footnotetext{
24 Ibid., pp. 428.

${ }^{25}$ Ibid., pp. 428-435.
} 
tariffs while Country A has many, unfairness obtains, irrespective of whether the incidence of protectionist measures employed by each country balances out at the national level.

National equal access reciprocity suffers from a fatal flaw, namely, it is insensitive to the fact that access to particular markets is valued differently by different countries. This insensitivity means that national equal access reciprocity generates perverse results. For example, it would regard as unfair a scenario in which Country A imposes a higher number of tariffs than Country $\mathrm{B}$, even if none of the tariffs imposed by A protect industries of particular value to $\mathrm{B}$, and none of the tariffs imposed by B protect industries of particular value to A. Conversely, it would regard as fair a scenario in which A and B impose the same number of tariffs, but in which A protects the industries of greatest value to B while B liberalizes the industries of greatest value to A. It is very hard to see how the second scenario could be fairer than the first. (Note that this argument does not appeal to the needs of developing countries.)

The same kinds of consideration that defeat national equal access reciprocity also reveal problems for sectoral equal access reciprocity. Suppose that Country A enjoys a comparative advantage in the production of Product $\mathrm{P}$, and thus has a special interest in Country $\mathrm{B}$ ceasing to protect its market for $\mathrm{P}$, while Country $\mathrm{B}$ enjoys a comparative advantage in the production of Product Q, and thus has a special interest in Country A ceasing to protect its market for Q. Now consider two scenarios. In the first scenario both A and B cease to protect their market for P, while continuing to protect their market for Q. In the second scenario, by contrast, A ceases to protect its market for $\mathrm{Q}$, while continuing to protect its market for $\mathrm{P}$, whereas $\mathrm{B}$ ceases to protect its market for $\mathrm{P}$, while continuing to protect its market for Q. Sectoral equal access reciprocity tells us that the first scenario is fairer than the second. But this result is rather puzzling. In the first scenario A gets what it wants, but B does not, while in the second scenario both countries get what they want. If either scenario is fairer than the other it is surely the 
second. (This argument, like the argument offered in the previous paragraph against national equal access reciprocity, does not appeal to the needs of developing countries.)

Sectoral equal access reciprocity faces an additional problem. According to this form of reciprocity, if Country A liberalizes a particular industry, Country B is compelled by fairness to reciprocate by also liberalizing that industry. But B may have a strong interest in refraining from liberalizing that industry, an interest which A lacks. For example, excessive subsidization of agriculture in developed countries has led to agricultural overproduction, while inadequate support for agriculture in developing countries has led to agricultural underproduction. Thus, developing countries have a strong interest, which developed countries lack, in subsidizing agriculture. But according to equal access reciprocity, if developed countries liberalize agriculture, fairness requires developing countries to follow suit. But this is bizarre. Why would fairness require two sets of countries to take the same course of action, when taking that course of action is economically sensible for one set but economically disastrous for the other?

These objections to national and sectoral equal access reciprocity suggest an alternative reciprocity principle. According to what we might call special interest reciprocity if Country A liberalizes a market of special interest to Country B, fairness requires B to reciprocate by liberalizing a market of special interest to A. Against special interest reciprocity it might be argued that developed countries are required to liberalize markets of special value to developing (or, at least, least developed) countries even if developing countries continue to protect markets of special value to developed countries. Such an argument would appeal to one of the rationales for SDT that we encountered in the previous section. For example, it could invoke the widely endorsed normative premise that if one is in a position to alleviate severe deprivation at little cost to oneself then one ought to do so, along with the empirical premises that (i) severe deprivation can be alleviated when rich countries liberalize the markets in which poor countries enjoy a comparative advantage, and that (ii) rich countries can liberalize those markets without incurring 
large costs. Premise (i) is widely accepted. Premise (ii) is slightly more controversial. When rich countries liberalize an industry, workers employed in that industry suffer as a result of exposure to foreign competition. Indeed, if imports substitute for domestically produced goods, many will lose their jobs. But, as economists have been keen to stress, these workers can be compensated. The national income gains brought about by liberalization can, in principle, be redistributed so that everyone benefits. ${ }^{26}$

In defence of developed countries only liberalizing markets of special value to developing countries on the condition that developing countries reciprocate, one might argue that it is in developing countries' own interest to liberalize their markets, and then add that making liberalization conditional in the way described is an effective way of making them do so. But arguing that conditional liberalization by developed countries can be an effective tool for getting poor countries to help themselves is very different from arguing that there is unfairness when poor countries fail to reciprocate liberalizing efforts made by rich countries. Since it is the latter argument that would have to be made by proponents of special interest reciprocity, the former argument cannot play a role in vindicating special interest reciprocity.

Moreover, the claim that it is always in the interest of developing countries to liberalize their markets is highly controversial. By contrast, the claim that developing countries benefit in terms of poverty alleviation when developed countries liberalize the markets in which the former enjoy a comparative advantage is, as I have already noted, widely accepted. Thus, one might plausibly insist, against special interest reciprocity, that developed countries are required to cease

\footnotetext{
26 Nicholas Kaldor, "Welfare Propositions of Economics and Interpersonal Comparisons of Utility", Economic Journal, Vol. 39, 1939. Some people might object to this claim on the grounds that such compensation will inevitably be what Robert Goodin has called "ends-displacing" compensation. (Robert E. Goodin, "Theories of Compensation”, Oxford Journal of Legal Studies, Vol. 9, No. 1, 1989, p. 60.) Ends-displacing compensation amounts to "forcibly shifting [people] from one set of plans and projects to another", and thus compromises individual autonomy (pp. 68-69). However, as Goodin notes, there will sometimes be "all sorts of reasons" for or against pursuing a particular policy (such as trade liberalization), and the fact that the costs associated with the policy can only be offset by ends-displacing compensation is "just one among many" (p. 75). He concludes that "on balance we may well decide that it is best to go ahead with the policy" (p. 75). Elaborating, we can say this: provided that ends-displacing compensation is sufficiently generous, trade liberalization plus compensation can be tolerable even if it compromises autonomy to some degree.
} 
protecting markets of special interest to developing (or, at least, least developed) countries, irrespective of whether or not those countries are willing to reciprocate, on the grounds that doing so is a low cost way of alleviating severe deprivation.

In this section I have shown how we can reject the claim that the principle of reciprocity - whether conceived of as national equal access, sectoral equal access, or special interest reciprocity - is a requirement of fair trade. Moreover, I have shown that national and sectoral equal access conceptions of reciprocity are vulnerable to damaging objections even when the needs of developing countries are set aside.

\section{III}

\section{Harmonization}

So far we have considered the claim that fair trade requires formal equality in the area of "at-theborder policies" such as tariffs and quotas. In recent decades it has been claimed that fair trade also requires formal equality in the area of "behind-the-border policies". It has become common to claim that, in order for trade to be fair, some subset of the domestic laws or policies of trading countries (e.g. labour or environmental laws) must be made more similar, or harmonized. The term "harmonization" is somewhat misleading. As David Leebron has observed

[t]he term "harmonization" is something of a misnomer insofar as it might be regarded as deriving from the musical notion of harmony, for it is difference, not sameness, that makes for musical harmony ... The claim for the harmonization of laws has come to mean something quite different - indeed almost the exact opposite of the musical notion of harmony - namely, that international trade relations will not run smoothly, or properly, unless the laws and policies of different jurisdictions are made more similar. ${ }^{27}$

${ }^{27}$ David W. Leebron, "Lying Down with Procrustes: An Analysis of Harmonization Claims", in Bhagwati and Hudec (eds.), Fair Trade and Harmonization: Volume 1 - Economic Analysis, (Cambridge, Mass: MIT Press, 1996$)$, p. 43. 
Calls for harmonization are motivated by a variety of considerations. The claim, for example, might be that trade relations will not run "properly" in the sense that they will not run efficiently in the absence of harmonization ${ }^{28}$; or the claim might be that trade relations will not run "properly" in the sense that they will not be fair in the absence of harmonization. Of interest to us are harmonization claims motivated by a concern for fairness. As Leebron points out, such claims are highly prevalent. He writes:

Recently, claims for harmonization of national laws and policies have been closely linked to claims for "fair trade". The scholarly literature has begun to embrace the notion that harmonization is the mechanism by which unfair differences in legal and other regimes are eliminated, and the level playing field, the metaphorical symbol of fairness, is restored. ${ }^{29}$

Leebron identifies three types of harmonization claim: pure normative harmonization claims, pure non-normative harmonization claims, and what we might call mixed harmonization claims. ${ }^{30}$ Pure normative harmonization claims maintain that all countries should adopt policy $\mathrm{P}$ because $\mathrm{P}$ is better, in some regard, than all alternative policies. Pure non-normative harmonization claims allege that all countries should adopt the same policy, because doing so is necessary to achieve some value (e.g. fairness or efficiency), but do not claim that any particular policy is better than any other. All that matters is that countries adopt the same policy; it does not matter which policy they adopt. Mixed harmonization claims incorporate both normative and non-normative elements. They call for all countries to adopt policy $\mathrm{P}$ because (i) the realization of some value requires that all countries adopt the same policy, and (ii) $\mathrm{P}$ is better, in some regard, than all alternative policies.

\footnotetext{
${ }^{28}$ For example, one might point out that the existence of different regulatory requirements in each country can deter producers from engaging in international trade. As Leebron writes: "Even where the marginal compliance costs for different jurisdictional requirements are low... legal information costs represent an additional fixed cost for each jurisdiction that must be recovered from the sales of products in that jurisdiction. In the face of ignorance and uncertainty, a producer might be unwilling to undertake the effort to engage in a small number of international transactions. In short, every separate legal system to some extent creates a barrier to trade.” Ibid., p. 62.

${ }^{29}$ Ibid., p. 41.

${ }^{30}$ Ibid., pp. $50-1$.
} 
Leebron notes that there is a sense in which pure normative harmonization claims are not bona fide harmonization claims. He observes that

[t]he apparent harmonization claim results only from a truism: every nation should have a law or policy $\mathrm{x}$; therefore, all nations should have the same policy. But here the only claim for harmonization is that all nations adopt policy $\mathrm{x}$; there is no claim independent of policy $\mathrm{x}$ that all nations should have the same policy. ${ }^{31}$

I will not discuss pure normative harmonization claims in isolation, but I will briefly consider the normative aspect of a common mixed harmonization claim. Let us begin, though, by considering pure non-normative harmonization claims. To repeat, according to these claims, in order for a particular value - in our case, fairness - to be respected, all trading countries must adopt the same policy, but it does not matter which policy they adopt because there is no policy the adoption of which is any better than any other. The upshot is that unfairness arises when Country A pursues policy P while Country B pursues policy Q, or vice versa, even if there is no unfairness or injustice inherent in the pursuit of $\mathrm{P}$ or the pursuit of $\mathrm{Q}$.

This might be because fairness requires the realization of goal $G$, and $G$ can be realized either by A and B both pursuing $\mathrm{P}$, or by $\mathrm{A}$ and $\mathrm{B}$ both pursuing $\mathrm{Q}$, but not by $\mathrm{A}$ pursuing $\mathrm{P}$ while $\mathrm{B}$ pursues $\mathrm{Q}$, or vice versa. In the context of international trade, the goal ostensibly sought by those who advance fairness-based harmonization claims is invariably a "level playing field". The claim is that unless certain policies are harmonized, firms or workers in one country will enjoy an unfair advantage over firms and workers in another. A non-normative fairness-based harmonization claim might maintain, for example, that while it is acceptable for A and B to implement a set of environmental laws $\mathrm{E}$, or to refrain from implementing $\mathrm{E}$, if $\mathrm{A}$ implements $\mathrm{E}$ while $\mathrm{B}$ does not, and if this reduces the production costs faced by firms in B, firms in B are given an unfair advantage over firms in A.

\footnotetext{
${ }^{31}$ Ibid., pp. 50-1.
} 
Suppose it is claimed that, by virtue of its lower environmental standards, Country B taken as a whole enjoys an unfair advantage over Country A taken as a whole. An obvious response to this claim is that A can benefit from cheaper imports made possible by B's lower standards. Or suppose it is claimed that all of the firms in A are unfairly disadvantaged by lower standards in $\mathrm{B}$. We can respond to this by pointing out that many firms can, and do, move production to where standards are lowest. A stronger non-normative harmonization claim would maintain that (i) relatively immobile workers in A are unfairly disadvantaged when competition from B forces the firms that employ them to lower wages, make layoffs, or move their operations abroad; or (ii) non-multinational firms based in A are unfairly disadvantaged when competition from B reduces their profits or puts them out of business. But even these claims are problematical because, in theory, the national income gains resulting from cheaper imports could be redistributed so as to compensate workers and non-multinational firms for the losses they suffer. ${ }^{32}$

Still, while A enjoys national income gains as a result of B's lower standards (e.g. because it can purchase cheap imports), B's income gains might be larger. Is that unfair? When attempting to answer this question it is important to notice that while $\mathrm{B}$ might benefit more in terms of national income, it does not follow that B benefits more overall, for B's lower standards may entail costs which, by virtue of its higher standards, A avoids. Indeed, if, as non-normative harmonization claims maintain, it is not impermissible for $\mathrm{A}$ to reduce its standards, there must be a reason why A chooses to maintain high standards. And one obvious reason is that the maintenance of high standards confers certain (non-income) benefits. Suppose the standards in question are environmental in character. By retaining high standards, A can benefit from a healthier and more pleasant environment. B might enjoy greater income gains, but only by sacrificing environmental quality. Thus, while we might be concerned about how much each

\footnotetext{
32 In practice, of course, compensatory redistribution will often face sizeable political obstacles. Harmonization might then be defended on the ground that it is the more practical policy. But this looks implausible. Suppose A attempts to achieve harmonization by getting B to raise its standards. What reasons are there for thinking that this will be any easier than motivating domestic support for redistribution? Alternatively, suppose A attempts to achieve harmonization by lowering its own environmental standards. Clearly this will also encounter fierce resistance.
} 
country benefits in relative terms from the policies they pursue, it is not at all obvious that, overall, B is better-off.

Non-normative fairness-based harmonization claims suffer from an additional limitation. When workers and firms believe the playing field is uneven, they invariably call upon their governments to demand that other countries change their laws. But non-normative harmonization claims cannot support these demands because, as we have seen, such claims do not identify one set of laws as superior to any other; they simply maintain that unfairness is a consequence of two or more countries adopting different, but equally acceptable, laws. Thus, if government A calls upon government B to change its laws in order to level the playing field, B can respond by insisting that if $\mathrm{A}$ is so concerned about levelling the playing field it should change its own laws.

Let us move on to mixed harmonization claims. ${ }^{33}$ These claim that fairness requires all countries to pursue policy P, rather than policy Q, because (i) the latter is unjust and (ii) would give any country pursuing it an advantage over those who do not pursue it which, by virtue of the unjustness of Q, would be an unfair advantage. Pure normative (pseudo) harmonization claims would also recognize the injustice of a country pursuing Q, but they would not recognize the putative unfairness which arises when some countries pursue Q while others pursue P.

One of the most commonly advanced mixed harmonization claims asserts that unfairness occurs when workers and firms in developed countries have to compete with workers and firms in poor countries where labour standards and minimum wages are unjustly low or non-existent. The fairness of competitive advantages traceable to low labour standards and wages has long been challenged. A memorandum circulated at the 1919 Paris Peace Conference - which gave life to the International Labour Organization (ILO) - revealed a concern on the

\footnotetext{
${ }^{33}$ Leebron claims that all harmonization claims motivated by a concern for fairness seem to "be based solely on the existence of difference" (i.e. are purely non-normative) (Leebron, p. 66). But, as I hope will become clear in the paragraphs that follow, fairness-based harmonization claims do not have to be construed in this way. Nor does it seem that those who have advanced fairness-based harmonization claims have understood themselves to be advancing purely non-normative claims; for, consider the reference to "oppressive" working conditions in the Peace Conference memorandum quoted in the text.
} 
part of the British delegation that "any state ... which does not carry out a Convention designed to prevent oppressive [working] conditions is guilty of manufacturing under conditions which create a state of unfair competition in the international market." 34

Several of the points made in the discussion of non-normative harmonization claims apply here too. If it is claimed that, by virtue of their lower labour standards and wages, developing countries enjoy an unfair advantage over developed countries, we can respond by pointing out that the latter can benefit from cheaper imports made possible by the former's lower standards and wages. ${ }^{35}$ Similarly, if it is claimed that all rich world firms are unfairly disadvantaged by lower standards in developing countries, we can respond by noting that many rich world firms can, and do, move production to where standards and wages are lowest. Indeed, the desire to attract multinational corporations is one of the things compelling poor countries to keep standards and wages low. A stronger claim would be that (i) relatively immobile workers in the developed world are unfairly disadvantaged when competition from developing countries forces the firms that employ them to lower wages, make layoffs, or move their operations abroad; or (ii) non-multinational firms based in the developed world are unfairly disadvantaged when competition from developing countries reduces their profits or puts them out of business. But, again, the national income gains resulting from cheaper imports could, in theory, be redistributed so as to compensate workers and non-multinational firms for the losses they suffer. $^{36}$

Still, when addressing this particular harmonization claim the fundamental question is whether the toleration of lower labour standards by developing country governments, and their refusal to implement or enforce satisfactory (or any) minimum wage laws, is actually unjust. If it is not, the harmonization claim collapses because one of its premises is revealed to be false. Is

\footnotetext{
${ }^{34}$ Quoted in Virginia A. Leary, "Workers' Rights and International Trade: The Social Clause (GATT, ILO, NAFTA, U.S. Laws)", in Bhagwati and Hudec (eds.), Fair Trade and Harmonization: Volume 2 - Legal Analysis (Cambridge, Mass: MIT Press, 1996), p. 186.

${ }^{35}$ Leebron, op. cit., p. 60.

${ }^{36}$ Ibid., pp. 60-1.
} 
the toleration of lower labour standards by developing country governments unjust? This is a difficult question, and it is not feasible to provide a wholly satisfactory answer here, but I can show that there are reasons to doubt that the answer will inevitably be affirmative.

Intuitively, the injustice of subsistence wages and miserable working conditions seems hard to deny. But one is given pause by the argument, often advanced by economists, that "sweatshop labour" can play a crucial role in an effective strategy of poverty alleviation. ${ }^{37}$ No doubt this argument is often invoked disingenuously by reactionary apologists for the status quo, but that is no reason to dismiss it. The argument runs roughly as follows. The lower production costs which come with lower wages and standards enable developing world firms to compete more effectively in the global market, and also to attract foreign direct investment (FDI). Foreign companies bring with them investment capital, cutting-edge technology, and advanced business, management, and marketing techniques. They provide their employees with valuable training, which they can take with them if they move to a different firm, and sometimes give technical and financial assistance to local contractors in order to enable them to meet the higher standards of foreign companies. This package of goods, it is argued, helps promote growth and reduce poverty. ${ }^{38}$

If it is to stand any chance of vindicating the use of sweatshop labour, this argument cannot simply claim that low wages and standards are one sufficient means among several for reducing poverty. Rather, the claim must be one of the following: (1) sweatshop labour is strictly necessary for poverty reduction, in the sense that poverty reduction would be literally impossible without it; (2) poverty reduction strategies which do not rely upon sweatshop labour are available, but they are morally inferior (because, say, they are much less effective, and would prolong the plight of the poor, or because they would violate the rights of others (imagine a

\footnotetext{
${ }^{37}$ See, for example, Paul Krugman, "In Praise of Cheap Labor: Bad Jobs at Bad Wages Are Better Than No Jobs At All" in his The Accidental Theorist And Other Dispatches from the Dismal Science, (New York: Norton \& Company, 1998).

${ }^{38}$ For a helpful review of the literature on the effects of FDI in developing countries see Stephen D. Cohen, Multinational Corporations and Foreign Direct Investment: Avoiding Simplicity, Embracing Complexity (New York: Oxford University Press, 2007), Ch. 8.
} 
government which seeks to alleviate domestic poverty by invading other countries and enslaving their citizens)); or (3) morally satisfactory alternatives exist, but the unjust behaviour of third parties renders them unavailable. (1) is undoubtedly false, but (2) and (3) are both much more plausible.

If it is reasonable for the governments of poor countries to believe that (2) or (3) are true, it is not obvious that it would be unjust for them to tolerate sweatshop labour. To be sure, patent injustices may have occurred along the way. It is possible to imagine a scenario in which (1) or (2) is true, but in which they were made true by unjust actions. And if (3) is true, it is unjust that others have acted in a way which has foreclosed the pursuit of strategies less burdensome to the global poor.

Nevertheless, if a government in the developing world reasonably believes that conditions (2) or (3) hold, a strong case can be made for the claim that their toleration of sweatshop labour is permissible, and perhaps even required. It can be argued that under such conditions, toleration of sweatshop labour is the least awful means with which developing world governments can enable their severely poor citizens to acquire the resources required to meet their most basic needs. Under such conditions, the argument continues, a developing world government would do its poorest citizens no favours by prohibiting sweatshops. Such a prohibition would simply deny them an opportunity which they may find more appealing than the other options available to them, such as scavenging for food on landfill sites. ${ }^{39}$

If the toleration of sweatshop labour by developing countries is consistent with justice, the common mixed harmonization claim that we have been considering collapses. It does not follow from this that any costs imposed upon workers or firms in the developed world by global

\footnotetext{
${ }^{39}$ Debra Satz makes a similar point about child labour: "bans on all child labor may drive families to choose even worse options for their children. Children ... are presumably better off working in factories than as prostitutes or soldiers." See Debra Satz, Why Some Things Should Not Be for Sale: The Moral Limits of Markets (Oxford: Oxford University Press, 2010), p. 163.
} 
free markets are fair; the corollary is simply that one cannot defend the claim that those costs are unfair by claiming that the toleration of sweatshop labour by poor countries is unjust. ${ }^{40}$

\section{IV}

In this paper I have sought to cast doubt on the claim that formal equality is a requirement of fair trade. Section I began by noting that the standard equity-based argument for formal equality does not fare well in the context of trade. I then moved on to show how preferential treatment for developing countries can be argued for and defended against a number of objections. Next, in section II, I demonstrated how to reject the claim that the principle of reciprocity - which requires states to match the liberalization efforts of others - should be regarded as a requirement of fairness. Finally, in section III, I examined and criticized a more recent interpretation of formal equality in trade, according to which some subset of the laws or policies of trading countries should be harmonized. ${ }^{41}$

Merton College, University of Oxford

james.christensen@merton.ox.ac.uk

\footnotetext{
40 It is worth noting that the mixed harmonization claim that we have been considering is arguably the most intuitively compelling mixed harmonization claim. The conviction that sweatshop labour is intolerable will surely feature as a provisional fixed-point in the reasoning of many readers. Other mixed harmonization claims have less intuitive force. See, for example, Aaron James's discussion of intellectual property harmonization in op. cit., Ch. 9.

${ }^{41}$ For valuable feedback on earlier drafts of this paper I am grateful to Simon Caney, David Miller, Stuart White, and two anonymous reviewers. For helpful discussion I am indebted to the members of the Nuffield Political Theory Workshop.
} 